IrynaTonkonoh,

$\mathrm{PhD}$, Associate Professor, Department of Foreign Philology and Translation, Kyiv National University of Trade and Economics

Kyoto Street, 19, Kyiv, Ukraine, 02156

e-mail: 197118@ukr.net

ORCID: 0000-0001-8488-8526

Yulia Yuvkovetska, $\mathrm{PhD}$, Associate Professor, Department of Foreign Philology and Translation, Kyiv National University of Trade and Economics Kyoto Street, 19, Kyiv, Ukraine, 02156 e-mail: yuwkowetzkayaj@gmail.com ORCID: 0000-0001-9212-6943

\title{
ANALYSIS OF THE CRUISE TOURISM SECTOR IN THE WORLD
}

This article examines the situation on the tourist cruise market over the last 3 years: cruise travel demand, the main consumer category, most common types of cruise tourism and the most popular tourist destinations. This is an important topic as the cruise tourism sector is developing rapidly, affecting tourism and the world's economy.

Keywords: cruises, cruise tourism market, river cruises, cruise product, the global maritime cruise industry market cruise companies, sustainability.

Relevance of research topic. The relevance of the topic is determined by the rapid growth in the recent years of the cruise industry in different regions of the world. Despite the rather high complexity and capital intensity, this specialty tourism area allows effective implementation of projects for the development of recreational, sports, wellness and cognitive tours. In addition, the cruise as a water transport trip includes shore excursions, sightseeing, and a variety of fun on board river liners, making it particularly attractive. At the same time during the cruise the tourist can spend time on board, relaxing and enjoying the service of a modern hotel on the water. All this objectively makes the destination of tourism attractive to more and more people who want to travel with comfort.

Analysis of recent researches and publications. Analyzing the development of cruise tourism in the world, I researched the publications of Ukrainian and foreign scientists, such as V. Kornilova and K. Nesterova, who researched the trends of cruise 
tourism development. I also looked at articles on sites related to the direct development of cruise tourism, such as publications by Cruise Line International Organization, Cruise Market Watch, and others. Analyzing this data has helped me to explore the cruise tourism market in detail and to identify the world's leading tourism companies.

\section{Presenting main material.}

The most common type of water travel is cruises. In 2017, 25.2 million people were served in the cruise tourism market ( $\$ 37.1$ billion), which is $6.6 \%$ more than in 2016 and $63.4 \%$ more than in 2007 [1]. The sustainability of the demand for the cruise product in the world in recent decades has been driven by the constant modernization of cruise ships, the formation of batch orders for the construction of new mega-liners, the upgrading and modernization of passenger berths, the improvement of port infrastructure.

There are such types of cruises: sea and river cruises. River cruises are the most popular in countries that have powerful river and lake systems as well as canal systems (the USA, Canada - Great Lakes (total length of the route along rivers, lakes and canals -over $40,000 \mathrm{~km}$ ). Similar cruises are made by the Nile, The Rhine, Danube, and now the river cruises are also organized by Lake Ladoga, the Volga, the Dnipro, Lena, Ob, Yangtze, canals and rivers of France and Sweden, and the Danube and Dnipro cruises to the Black Sea are popular in Ukraine. The lines include the village Be the following: AROSA, AmaWaterways, Avalon Waterways, CroisiEurope, Emerald, Scenic, Tauck, Uniworld Boutique River Cruise Collection, Viking Cruises $[2]$.

The volume of passenger traffic is led by the United States. They account for more than half $(51 \%)$ of the current number of cruise tourists -11.21 million people. The United States has relied on the creation of a high-quality and inexpensive mass cruise product. The US cruise industry market has created an exceptionally attractive and affordable service for residents of America, Europe and Asia. The second place is shared by Germany and the UK: $15 \%$ or 3.38 million passengers. The top three are Australia, Italy and Canada. Each of these countries accounts for 800,000 tourists $(12 \%)$. This is followed by China, France, Spain and Norway, which together provide another 2 million customers (or 10\% of the global figure). The demand structure by region undergoes significant changes in the period 2007 - 2017 (Fig. 1): from 90.6\% to $61.5 \%$ the volumes of flow to the most developed regions of the cruise market are reduced, namely: Caribbean and Bahamas, Europe, Mediterranean ; demand for products is emerging in Asia (especially China) and Australia [3]. 


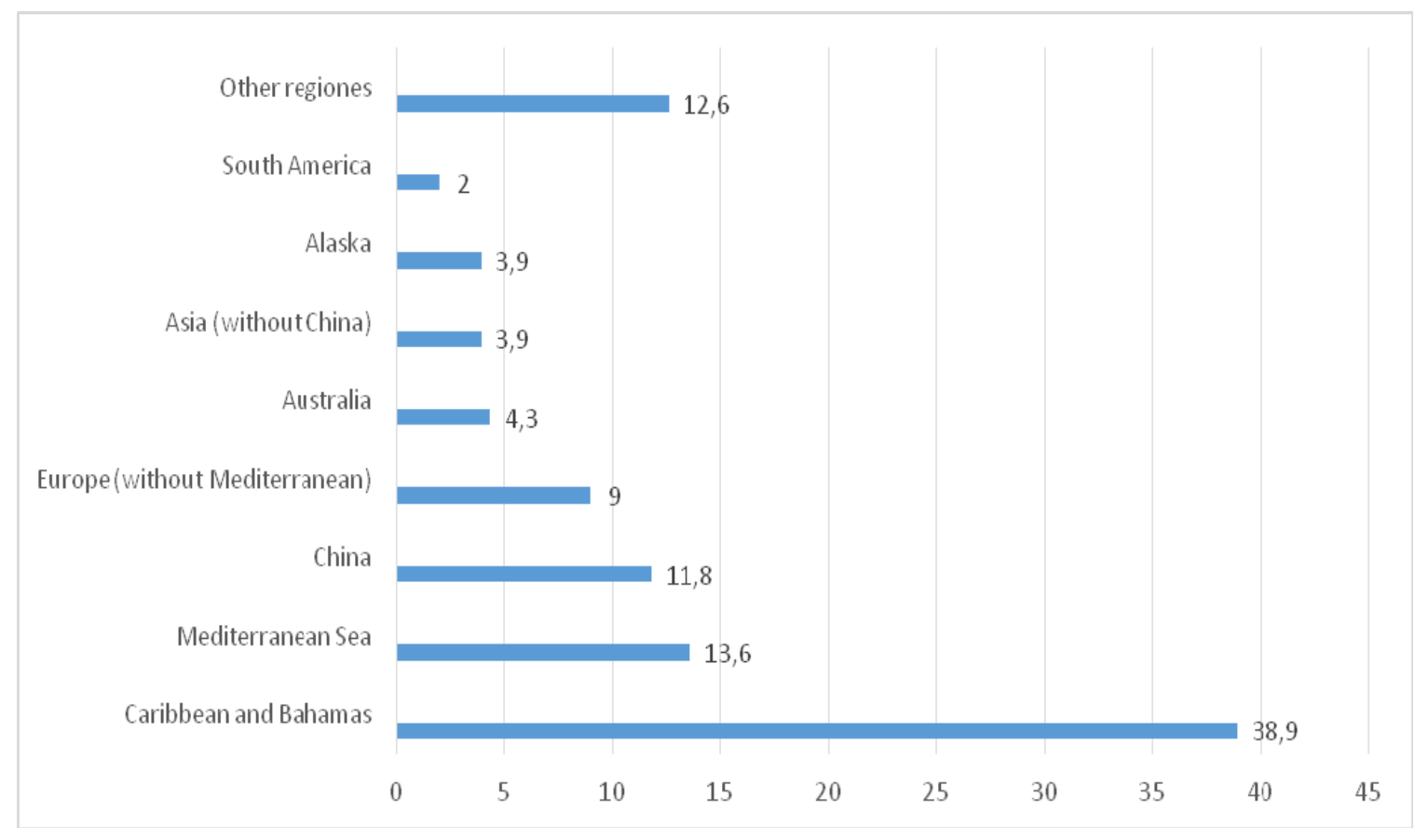

Fig. 1. Global Cruise Tourism Market Structure in 2017, \%

The age of modern cruise passengers is $40-50$ years. In the $2000 \mathrm{~s}$, this figure was at the level of 50-60 years, indicating the influx of younger consumers. According to experts, the age of cruise ship users will decrease annually and will be 35-40 years by 2020 [4, p. 40].

According to the FCCA (Floride-Caribbean Cruise Association), the main passengers of cruise ships are tourists from the USA, China, Germany, the UK and Australia (Fig. 2) [5].

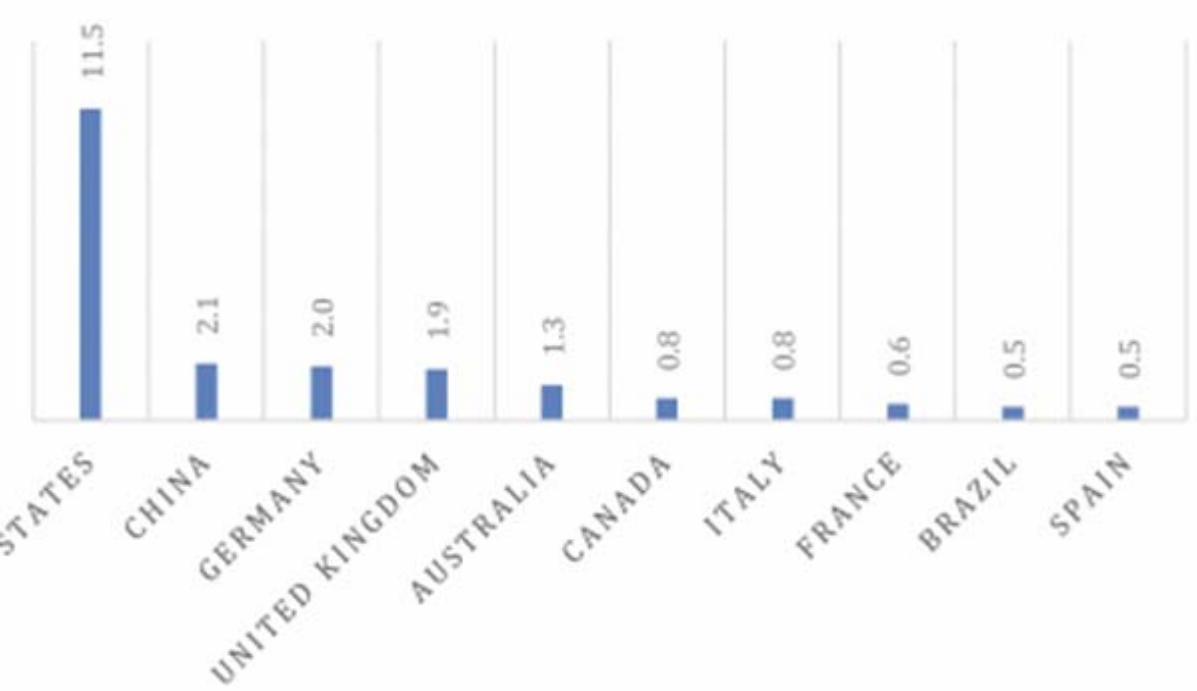

Fig. 2. Major Cruise Line Passengers in the World for 2016 (million people) 
Experts predict that in 2027 the capacity of the cruise tourism market will be more than 38 million people, which will provide a growth rate of $151 \%$ compared to 2017 (12.8 million more). To support the pace of market growth, investments in shipbuilding are being carried out, the course on technology innovation is being supported, and a policy on sustainable cooperation with supplier's partners is being implemented.

The global maritime cruise industry market is divided into 20 specialized companies, which in turn belong to 4 large groups. Tops the list of the largest cruise companies holding Carnival Corporation. The fleet of the largest of its brands Carnival Cruise Line, has more than 20 ships and is constantly updated with new ones. It is followed by Royal Caribbean International, and the Norwegian Financial Cruise Line (NCL) is in third place. All these carrier companies are based in the US. Fourth in the rating and the first cruise ship in Europe - MSC Cruises. Closes the Top 10 leading Spanish cruise companies Pullmantur.

Carnival holding companies control $44.8 \%$ of the world maritime cruise market. The share of the six shipping companies following the Royal Caribbean Group is 24.7\%. Further, the three Norwegian Cruise Line companies account for $8.9 \%$ of the market, while MSC Cruises holds $6.4 \%$. Almost $40 \%$ of the world's cruise ship routes are in the Caribbean, followed by the Mediterranean (17\%), and Asia Pacific (10.4\%). According to 2022 forecasts, Carnival Corporation will account for $42.1 \%$ of the cruise market, with a fleet of 113 vessels; on Royal Caribbean Cruises $-22.8 \%$ and 53 vessels respectively; MSC Cruises $-9.9 \%$ and 19 vessels; Norvegian Cruise Line $9 \%$ and 27 ships. Thus, these four companies will control $83.8 \%$ of the world cruise market, and their total fleet will be 212 vessels (Table 1) [6].

Table 1

The largest cruise companies in the world for 2020

\begin{tabular}{|c|l|c|c|c|c|}
\hline № & $\begin{array}{l}\text { The name of the } \\
\text { cruise company }\end{array}$ & $\begin{array}{c}\text { Number of } \\
\text { ships }\end{array}$ & $\begin{array}{c}\text { Beds, } \\
\text { thousands }\end{array}$ & $\begin{array}{c}\text { Passenger } \\
\text { capacity, } \\
\text { thousands of seats }\end{array}$ & $\begin{array}{c}\text { Market share } \\
\%\end{array}$ \\
\hline 1. & $\begin{array}{l}\text { Carnivals } \\
\text { Corporaton }\end{array}$ & 113 & 273,5 & 13404,0 & 42,1 \\
\hline 2. & $\begin{array}{l}\text { Royal Caribbean } \\
\text { Cruises }\end{array}$ & 53 & 144,3 & 7260,9 & 22,8 \\
\hline 3. & MSC Cruises & 19 & 63,0 & 159,3 & 9,9 \\
\hline 4. & $\begin{array}{l}\text { Norvegian Cruise } \\
\text { Line }\end{array}$ & 27 & 59,1 & 2878,3 & 9,0 \\
\hline
\end{tabular}

\section{Conclusion.}

The development of cruise tourism has a tremendous effect for local economy development: increase in revenues to budgets of all levels; job creation in cruise ship 
service areas catching; promotion of tourist opportunities in the region well (countries in general); empowering the internative cooperation; attraction of investments in development current transport and tourist infrastructure, etc. Therefore, cruise tourism is very profitable industry.

The largest share in the consumption of cruise services is native to North American countries. This is due to the relatively high standard of living in the region, the availability of adequate natural resources and so on.

European maritime tourism has a smaller volume of tourist cruise flows, but is increasing annually profits. Residents of European countries form up to $30 \%$ of global cruise market demand. Five countries operate in the European cruise lines, who share about $80 \%$ of their profits: Great Britain, Germany, Italy, Spain and France.

Recently, the Asian region stands out with $12-15 \%$ demand for cruise services. One of Asia's most promising countries for cruise tourism is China. Demand for Asian travel cruises slightly different from the world. Because the Chinese people mainly travel to Europe and their regions. And the Caribbean countries share in the demand structure insignificant and about $14 \%$.

The volume of passenger traffic is led by the United States. They account for more than half $(51 \%)$ of the current number of cruise tourists - 11.21 million people. Afterwards, cruise tourists suppliers are Germany, China, the United Kingdom, Australia, Italy and Canada. The age of modern cruise passengers is $40-50$ years.

The world market of the sea cruise industry belongs to 20 specialized companies, which in turn are subordinated to 4 large groups. According to forecasts until 2022four leading companies (Carnival Corporation, Royal Caribbean Cruises, MSC Cruises, Norwegian Cruise Line) will control 83,8\% of the world cruise market.

\section{REFERENCES}

1. The Global Economic Contribution of Cruise Tourism 2017. CLIA: [Electronic resource]. - URL: www.cruising.org/.../Global_Cruise_Impact_Analysis 017.pdf

2. Cruise Market Watch: [Electronic resource]. - URL: http://www. travelweekly.com/River-Cruising/Growth-spurt-river-cruising

3. V. Kornilova, Article. Current Trends in the Cruise Market in the World [Electronic resource]. - http://www.investplan.com.ua/pdf/5_2018/6.pdf

4. K. Nesterova, State Regulatory Policy for Promoting Sea Tourism in Ukraine: 08.00.03 - Economics and Management of National Economy. - NAS of Ukraine, Institute of Market Problems and Economic and Environmental Research. Odessa, 2016. -40 p.

5. Review of the Cruise Industry [Electronic resource]. - URL: https://www.fcca.com/downloads/2018-Cruise-Industry-Overview-and-Statistics.pdf

6. Cruise Line International Organization [Electronic resource]. - URL: http:// www.cruising.org/ 